\title{
DISCRIMINATION IN THE LABOR MARKET IN THE REGION OF SOUTH BOHEMIA
}

\section{DISKRIMINACE NA TRHU PRÁCE V JIGNÍCH LECHÁCH}

Ing. Jaroslav VRChOTA, Ph.D.

ING. MoNIKA ĠVÁROVÁ

\section{BC. KLÁra KUBEĠová}

\author{
Katedra Śzeni $\mid$ Department of management \\ Ekonomická Fakulta Faculty of Economics \\ Jihol eská univerzita $v$ Leských Bud円jovicích University of South Bohemia \\ $\bowtie$ Studentská 13, 37005 Ḷeské Bud円ovice, Czech Republic \\ E-mail:vrchota@ef.jcu.cz,monika.svarova@gmail.com,kubesk@gmail.com
}

\begin{abstract}
Annotation
The goal of this paper is to analyze the current state of the labor market in the South Bohemian region characterizing the most common forms of perceived discrimination on the basis of field surveys. Data were collected from 168 respondents during the autumn 2013. Based on the analyzed data, it was found that most people experience discrimination around the age of 45 years and the most frequent forms of discrimination reported are age, gender, and possibly parenthood. An interesting finding was that discrimination in the labor market much more effect men than women.
\end{abstract}

Key words

labor market, discrimination, South Bohemia Region

\section{Anotace}

Cílem pŚsp円 $\mathrm{ku}$ je analyzovat souḷ asný stav na trhu práce v jihol eském regionu charakterizováním

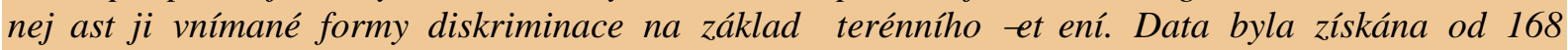
respondent $\mathrm{T}, \quad b$ ḩem podzimu 2013. Na základ円 analyzovaných údaj丁 bylo zjiğhno, ǵe nejvíce

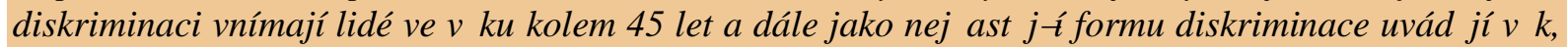
pohlaví a pŚ́padn门 rodil ovství. Zajímavým zjiğnním bylo, ǵe se $s$ diskriminací na pracovním trhu mnohem ! ast Đi setkávají muği oproti ǵenám.

\section{Klị ová slova}

diskriminace, trh práce, Jihoḷ eský kraj

JEL classification: $X 12$

\section{Introduction}

"Work occupies in human life irreplaceable position. It is an important precondition for its dignified existence, he brings not only material benefits, but it also gives him a sense of fulfillment and social utility. Gives man social relations, satisfying the needs of his ambition, self-fulfillment and selfesteem "(Buchtová et al., 2002).

In today's hectic world, characterized by very competitive fight and increasing pressure on rising labor productivity, for some groups are more difficult to apply in the labor market. For many employers is easier to appoint a person by social opinion "smooth" than the person chasing the shadow of 
stereotypical assumptions concerning the age, gender, disability, race, etc. The paradox is that in the course of life, each person is holder of potential discriminatory reason. Discrimination is a global problem. (Nickell, 1990; Halásková, 2008). As noted by sociologist Manuela Tomei: "It is remarkable that discrimination is everywhere, regardless of how the country is rich or poor or what type of political system it has."

"Discrimination is a general term for differentiation, for a different approach. Typically to the groups of a certain age, gender, racial or ethnic origin, to the groups who belong to a particular culture, religion or groups that have a disadvantage, or marginal social status. These groups may be systematically favored or disadvantaged by the laws, by regulations, publicity, prejudice, and especially by actual behavior of people with whom these groups of people come into contact" (Matouǵke, 2003).

Anti-Discrimination Act divide discrimination into direct and indirect, harassment, sexual harassment, instruction to discriminate and incitement to discrimination. As reported by Bobek et al. (2007), direct discrimination is when a particular person or group of persons is treated in a comparable situation less favorable than other people (Browne, 2009): a) on the basis of impermissible criteria (race, gender, nationality, religion, etc.), b) without reasonable justification. For indirect discrimination, according to the Anti-Discrimination Act is "any act or omission which, under an apparently neutral provision, criterion or practice is at a disadvantage compared to the other person (Goldscheider, 1992). Indirect discrimination on grounds of disability shall also mean refusal or failure to take reasonable steps to ensure that the person with disabilities have access to a specific job, to perform work or other promotion, in order to take advantage of career counseling or participate in other professional education, or to be able to use the services to the public, unless such measures would impose a disproportionate burden (Kane, 1998).

\section{Methodology}

The goal of this paper is to analyze the current state of the labor market in the South region characterizing the most common forms of perceived discrimination on the basis of field surveys. Data were collected from 168 respondents, during autumn 2013, thanks to an anonymous questionnaire survey in paper and electronic form.

The questionnaire was composed of 20 questions ( 3 filter questions, 7 identifying, 10 thematic), the questionnaire used both closed (13), half-closed, (4) open (1) or more criterion (2). Were distributed 70 printed questionnaires, which return was $76 \%$ (53 questionnaires). In the electronic version of the 107 respondents answered. Total counted 168 valid responses. For incomplete data were excluded two questionnaires. The group of respondents can be described in 107 women $(64 \%)$ and 61 men (36\%), of which $53 \%$ were single, $41 \%$ married, married and divorced $6 \%$. Furthermore, respondents can be divided according to age see Table 1, the largest component of the group acquired under the age of 25 years.

\section{Tab. 1: Representation of respondents}

\begin{tabular}{|l|c|c|}
\hline Age range & Number & $\%$ \\
\hline $15-24$ years & 52 & $31 \%$ \\
\hline $25-34$ years & 38 & $23 \%$ \\
\hline $35-44$ years & 35 & $21 \%$ \\
\hline $45-54$ years & 26 & $15 \%$ \\
\hline 55 years and more & 17 & $10 \%$ \\
\hline
\end{tabular}

Source: own research

At the same time in terms of research to take account of the progress of education of respondents, where it represented $28 \%$ of university graduates, $5 \%$ college graduates, $50 \%$ high school graduation, $15 \%$ of apprentices and $2 \%$ to basic education. From the perspective of discrimination was also significant their current form of employment, 53\% were employed as standard, $11 \%$ were 
self-employed, and $9 \%$ were unemployed, $4 \%$ retirement and $23 \%$ of students. Of the employed in the private sector was $72 \%$ and $28 \%$ in the public sector, where according to a study by Pincus (1996), people often encounter less discrimination.

A questionnaire survey was conducted only in the South Bohemian region. Responses were coded according to a predetermined coding framework, followed transfer of data into electronic form. With the help of a filter function data were categorized by gender, education, age, marital status and number of children respondents, subsequently, each issue drawn up summarizing table. The processing and presentation of data was used MS Excel software.

\section{Results}

Research has generally focused on forms of discrimination and general perceptions and experiences with this issue. A total of $52 \%$ of respondents thought that discrimination in the labor market certainly is (see Chart 3). The fact that discrimination occurs sometimes believes $37 \%$ of the respondents and the other $11 \%$ of survey participants think that discrimination is no more. Neither respondent does not believe that discrimination in the labor market in the Czech Republic does not exist, detailed structure is evident from Table 2. About existence of discrimination in the labor market are convinced more women $(92 \%)$ than men $(82 \%)$.

\section{Tab. 2: Experiences of discrimination}

\begin{tabular}{|l|c|c|c|}
\hline & Overall & Men & Women \\
\hline Yes & $52 \%$ & $54 \%$ & $50 \%$ \\
\hline Rather yes & $37 \%$ & $28 \%$ & $42 \%$ \\
\hline Rather no & $11 \%$ & $18 \%$ & $7 \%$ \\
\hline No & $0 \%$ & $0 \%$ & $0 \%$ \\
\hline
\end{tabular}

In the fact that the labor market discrimination exists, are the most confident respondents in the age group 45 years and over $(60 \%)$, the least voted for this option was from aged 35 - 44 years $(38 \%)$ and $54 \%$ of respondents aged 35 - 44 years believe that discrimination more likely occurs. People from 25 to 34 years, chose this response by $33 \%$. Possibility that probably not exist the least occurred in persons aged 45 years and over (5\%). Opposite opinion, most of the respondents were ages 25 - 34 years, where this variant occurred in $16 \%$ of responses. The most varied responses were in the category of 15 - 24 years. While women answered this question: yes $(54 \%)$, rather yes $(38 \%)$, probably not $(8 \%)$, no $(0 \%)$. Men were more likely to believe that discrimination is no more or less chose the answer yes. The specific composition of their answer is: yes (38\%), rather yes $(38 \%)$, probably not $(24 \%)$, no $(0 \%)$.

Yes, labor market discrimination occurs, was the most common choice of secondary education without GCE (58 \%), the lowest among respondents with higher professional and university education, but even though $50 \%$ of those surveyed believe that discrimination in the labor market occurs. ÄProbablyñ variant was consistently collected (38\%) by secondary educated without GCE and secondary educated with diploma. As with the previous answers, respondents answered as follows at least a higher education (25\%). University-educated respondents hold the view that discrimination in the labor market rather not, $13 \%$ exist. At least this is the opinion of secondary educated.

Personal experience of discrimination in the labor market has $24 \%$ of respondents, almost half (47\%) heard about it and only $29 \%$ of the respondents discrimination in the labor market did not encounter ever (Chart 1). The survey shows that the personal discrimination encountered more men than women. Personal experience has shown $56 \%$ of women 15 to 34 years, namely $19 \%$ of women aged $15-24$ years and $37 \%$ of women aged 25-34 years. This experience has $17 \%$ of women aged 35-44 years and 45 years or more. Hearsay knows about discrimination in the labor market, $52 \%$ of women aged 15 - 24 years, $42 \%$ aged 24 - 35 years, $50 \%$ between 35 - 44 years and $58 \%$ of women 45 years and older. 
With no discrimination meet only $29 \%$ of women 15 to 24 years, $21 \%$ of 25 - 44 years, $33 \%$ of 35 - 44 years and women at least 45 years of age and over $(25 \%)$.

\section{Fig. 1: Encounter discrimination}

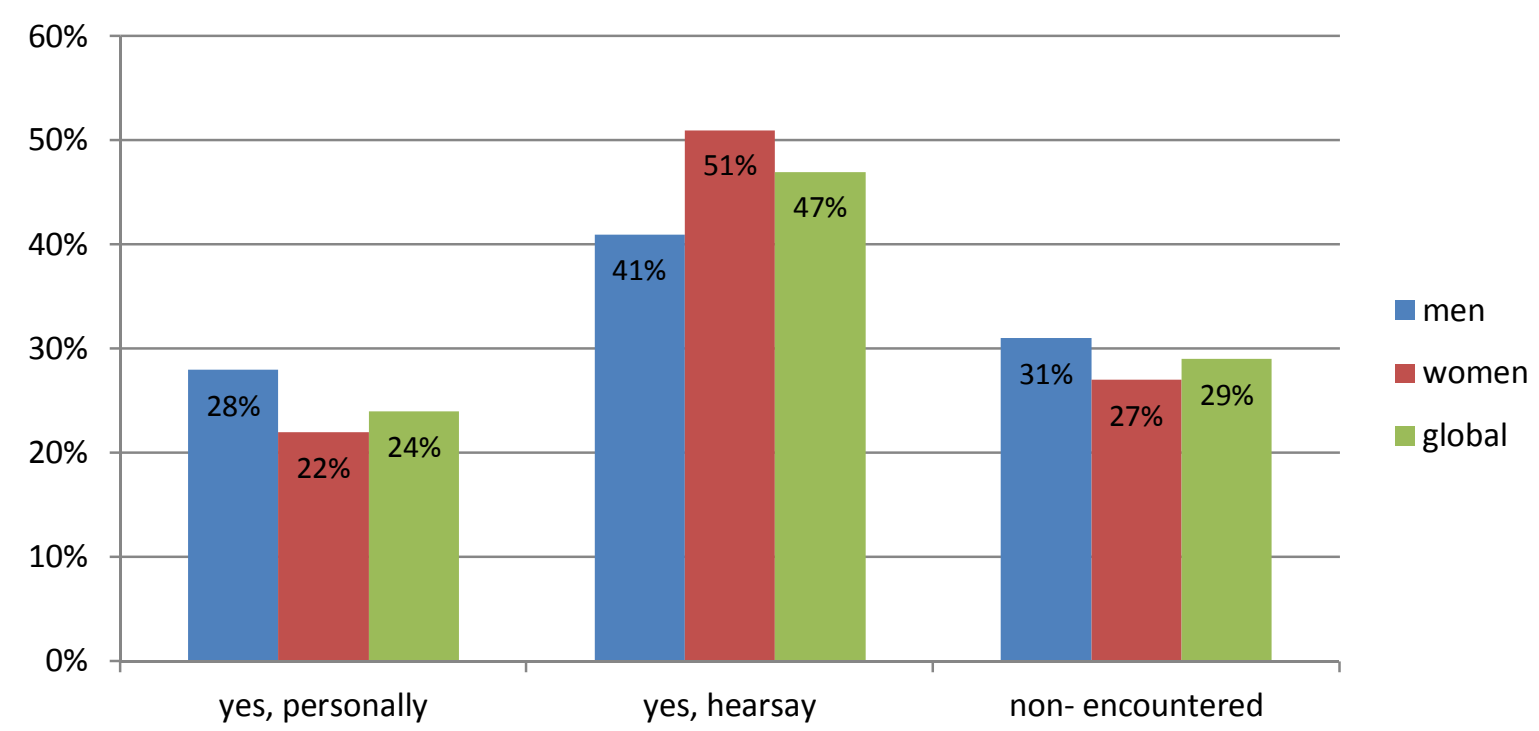

Source: own research

Personal experience reported $38 \%$ of men aged 45 years and over, $33 \%$ in the age group 25-34 years and $23 \%$ of men 15 to 24 years. There was nobody in the range of $34-44$ per survey not discriminated against. Most of personal discrimination in the labor market has met women with secondary education with GCE and women with college education, reported as both $28 \%$. Number of university graduates with direct experience counts $21 \%$, secondary education without GCE of $17 \%$. Almost half of university-educated men stated that they had personally experienced discrimination in the labor market, which is much more than well-educated women. The smallest confirmed experience with secondary education without GCE (14\%). Men with secondary education (with GCE) experienced personal discrimination by $22 \%$.

\section{Fig. 2: Place of discrimination}

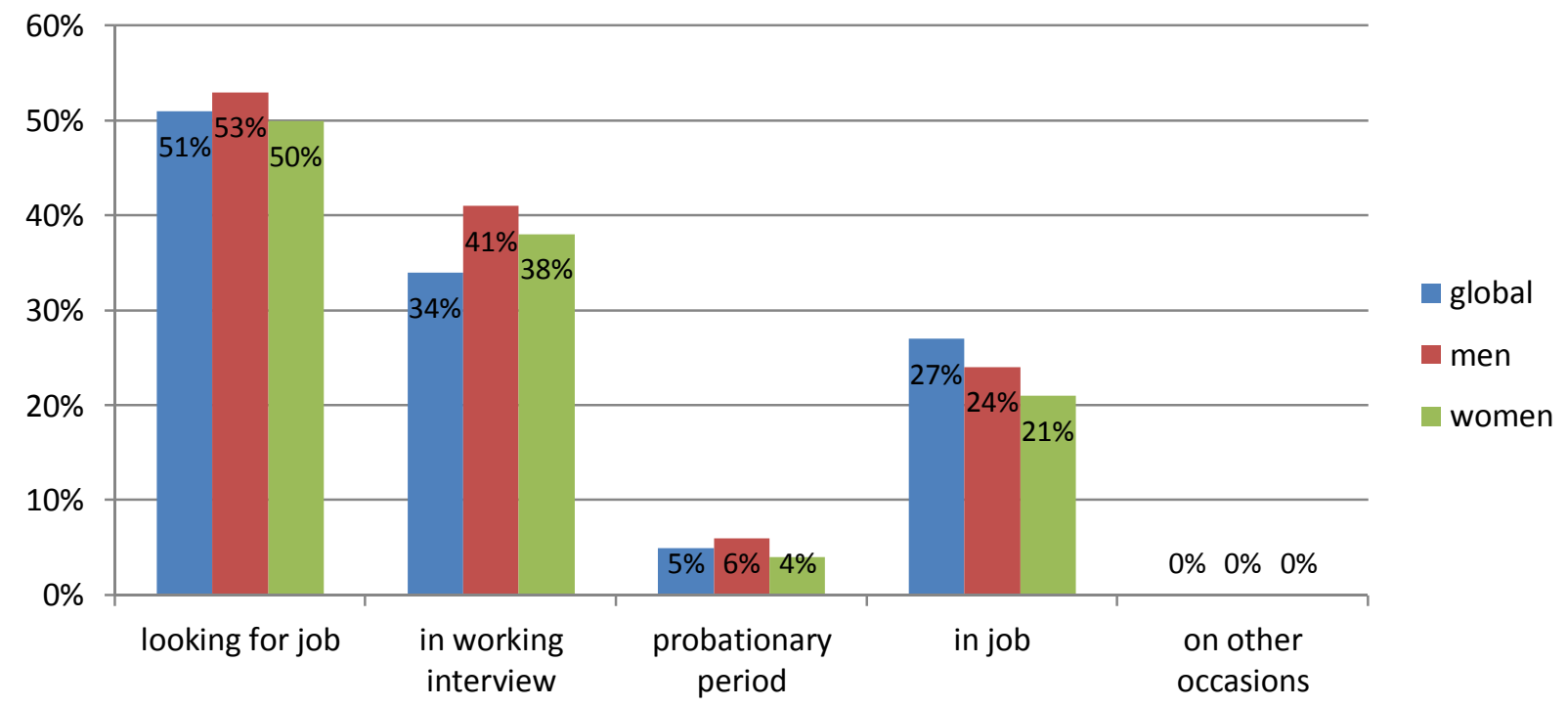

Source: own research 
Following the previous question, most frequently discrimination respondents encountered already during the job search, such experience have $20 \%$ of those who reported personal contact with discrimination. Furthermore, $34 \%$ of respondents said that they were discriminated against in a job interview. During the trial period experienced discrimination $5 \%$ of respondents in employment and $27 \%$ of those surveyed (Figure 2). When job search with discrimination encountered $7 \%$ of respondents aged 15 - 24 years, $20 \%$ aged 25 - 34 years, $20 \%$ older than 45 years and no respondent aged 35 - 44 years, who confirmed the previous question personal experience. In the interview confirming the discriminatory conduct $60 \%$ of people over 45 years old, just $45 \%$ of respondents in the age range $25-34$ years, $10 \%$ aged $25-34$ years, $20 \%$ aged $15-24$ years and none aged $35-44$ years. During the trial period you feel discriminated against, only respondents aged 25 - 34 years, namely $10 \%$ of them. Minimum experiences of discrimination in the workplace have respondents aged $15-24$ years and 25 - 34 years, while most respondents older than 45 years.

The most commonly reason for discrimination in all age groups of respondents was age (Figure 2). Overall $82 \%$ respondents answered that. The second most frequent cause for discrimination by the respondents was parenting, but there is a big difference in the responses of men (44\%) and women who parenthood as a reason for discrimination marked more frequently $(73 \%)$. Another $53 \%$ of respondents said sex. Even here is difference in the responses of men (44\%) and women (59\%). The fourth most frequent responses were health $(34 \%)$. Furthermore, $30 \%$ of the respondents said nationality, $11 \%$ said marital status and sexual orientation said $10 \%$ of respondents. At least reported reasons were political opinions and religious beliefs that have received both $2 \%$.

\section{Fig. 3: Discrimination area}

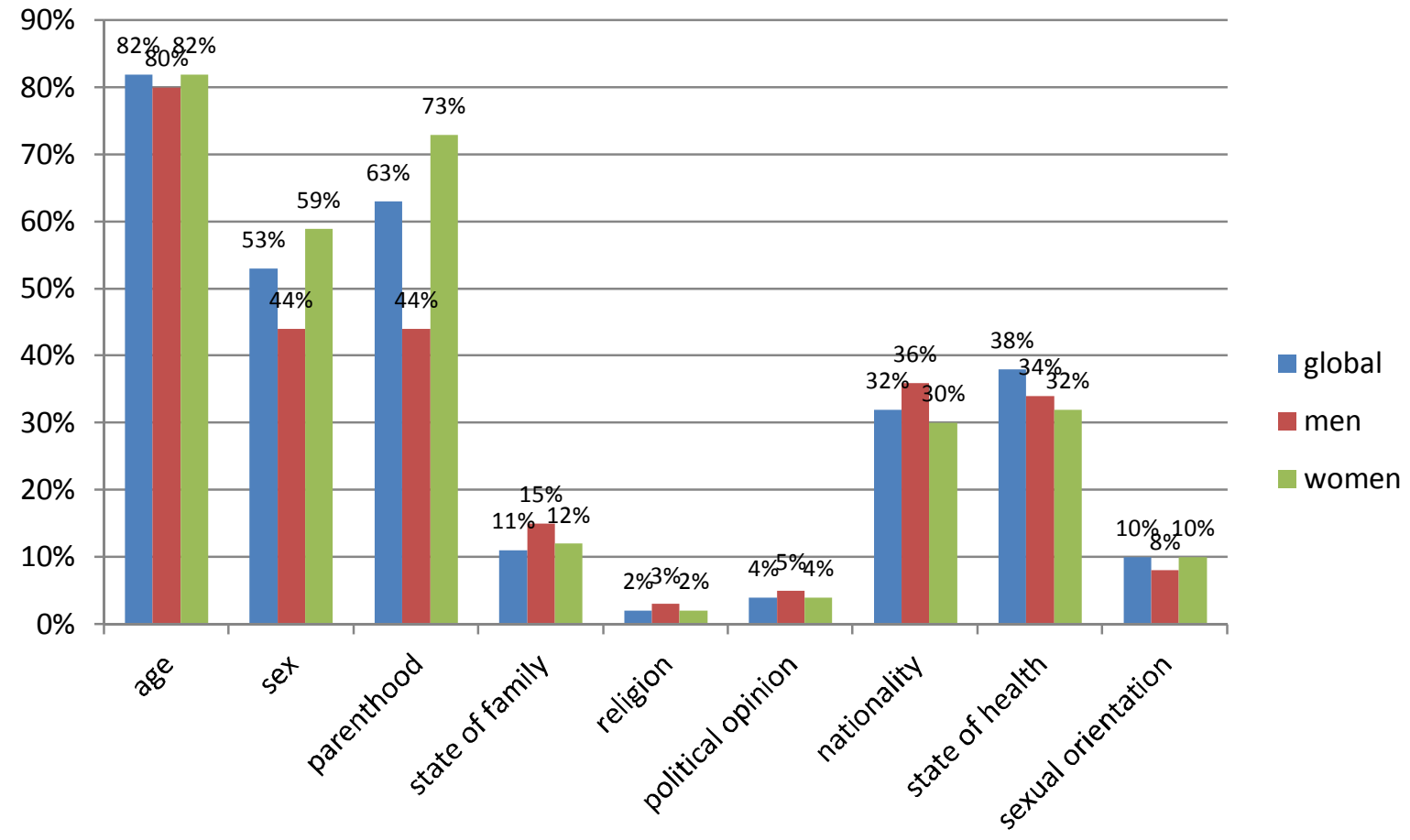

Source: own research

On this question, the answers in the first place distinction among respondents 15 to 24 years and 45 years or more. While respondents from the category of 15 - 24 selected in $72 \%$ parenting as the most common reason for discrimination, persons aged 45 years and over thinks that $42 \%$ less, particularly so think $30 \%$ of them. Conversely age considered the most serious, and that $95 \%$ of respondents aged 45 years or more in the category of 15 to 24 years, this discriminatory reason appeared in $73 \%$ of those surveyed. Another major distinguishing the answers of respondents aged 35 - 44 years and 45 years and more specifically the possibility of marital status, while respondents from 35 to 44 years old 
often mentioned the possibility of parenthood (85\%), the same answer said "only" $30 \%$ of respondents aged 45 years and over.

According to the respondents, is clearly the most discriminated group of people aged 55 and more. As the second most discriminated group respondents consider the age group 25 - 34 years $(18 \%)$. This answer was chosen $23 \%$ of women, but for men with this variant appeared to fourth place, in total 10 $\%$ said so. As the third most vulnerable group the respondents consider aged 35 - 44 years, expressed as the $17 \%$ of respondents. It was there a noticeable difference in the responses of women and men, chosen as $21 \%$ of women and "only" $12 \%$ of men. Almost the same number of women $(12 \%)$ and men $(13 \%)$ has chosen the most discriminated category of $15-24$ years. The remaining $7 \%$ of the total number of respondents referred to persons aged 65 years and over (4\%) and 35 - 44 years (3\%). There was no one believes that discrimination does not occur in any groups.

\section{Conclusion}

Discrimination in the labor market is not only the domain of Czech Republic, is strongly rooted in other countries of the world (Bimrose et al., 2014). Lanning (2014) in his research shows that discrimination and wage gaps persist despite pressure from the political sphere. Even the policy of equal pay may paradoxically further increased the wage gap. Also, the effectiveness of equal pay for work in one company and due to sex may vary. Chalikia (2013) describes how often condemns discrimination, but many businesses it very often tolerated.

The results show that the discrimination occurring believe all respondents, regardless of gender, age or education. In terms of understanding discrimination as a social problem that should be addressed, it's not so clear. In that are convinced mostly people over 45 , which can be attributed to the fact that these people are among the most vulnerable groups in the labor market. Older people encounter the problem of age discrimination, although they are suited and often a lot of experience for the performance, writes Nevhin (2012).

Although the survey shows that personal experience of discrimination has more men. This finding cannot be generalized and say that the men in the labor market are more discriminated. The result is influenced by the low number of respondents; therefore, in this respect cannot make meaningful conclusions. However, the finding that the personal experience of discrimination has $24 \%$ of the respondents is quite alarming. Older people and women are also confident about the growing trend of discrimination.

Despite numerous legal measures such unacceptable behavior does not occur sporadically. There are several reasons. Discrimination in almost all forms is very hard to prove. Although the burden of proof is on the defendant, very few cases reach up to the judicial system. This is related to other negative findings, a very low level of awareness of citizens on the right of this issue. Only $17 \%$ of respondents demonstrated knowledge of a specific piece of legislation. Even though, $64 \%$ of respondents consider protection in the Czech Republic as poor. It is therefore necessary to educate society in this area. Too many laws and regulations may have an opposite effect, which will discourage the employment of risk groups. It is important to ensure the quality of the protective measures and compliance, than quantity, leading to deterioration of the situation.

\section{References}

[1] Bimrose, J., WATSOn, M., MCMAHON, M., HAASLER, S., TOMASSINI, M., SUZANNE, P. A., (2014). The problem with women? Challenges posed by gender for career guidance practice. International Journal for Educational and Vocational Guidance, vol. 14, iss. 1, pp. 77-88. ISSN 1573-1782. DOI 10.1007/s10775-013-9256-9.

[2] BOBEK, M., BOUĹKOVÁ, P., KÜHN, Z., (2007). Rovnost a diskriminace. Praha: C.H.Beck. ISBN 97880-7179-584-1. 
[3] BROWNE, A., (2009). The Retreat of Reason. Politoval correctness and the corruption of public debate in modern Britain. Praha: DokoŚn. ISBN 978-80-7363-240-3.

[4] BUCHTOVÁ, B., (2002). Nezam П̧tnanost: psychologický, ekonomický a sociální problém. Praha: Grada. ISBN 80-247-9006-8.

[5] GOLDSCHEIDER, F. K., GOLDSCHEIDER, C., (1992). Gender Roles, Marriage, and Residential Independence. Sociological Forum, Plenum Publishing Corporation, vol. 7, iss. 4, pp. 679-696. ISSN 15737861. DOI 10.1007/BF01112321.

[6] HOLÁSKOVÁ, R., (2008). Politika zamß̧tnanosti. Ostava: Ostravská univerzita v Ostravク ISBN 978-807368-522-5.

[7] CHALIKIA, M. H., HINSZ, V. B., (2013). Sex-Based Salary Disparity and the Uses of Multiple Regression for Definition and Remediation. Current Psychology, vol. 32, issue 4. ISSN 1936-4733. DOI 10.1007/s12144-013-9191-4.

[8] KANE, E. W., (1998). Men's and Women's Beliefs about Gender Inequality: Family Ties, Dependence, and Agreement. Sociological Forum, vol. 13, iss. 4, pp. 611-637. ISSN 1573-7861. DOI 10.1023/A:1022895317075.

[9] LANNING, J. A., CHEN, J-J. J., CHEN, L-H., CHIANG, P-T., LEE., H-Y., (2014). A search model with endogenous job destruction and discrimination: Why equal wage policies may not eliminate wage disparity. Labour Economics, vol. 26, iss. 1, pp. 55-71. ISSN 1467-9914. DOI 10.1016/j.labeco.2013.11.001.

[10] MATOUĠE, O., (2003). Slovník sociální práce. Praha: Portál. ISBN 78-80 -7367-368-0.

[11] NICKELL, S., (1990). Unemplyment: A Survey. The Economic Journal, vol. 100, iss. 401, pp. 391 ï 439. ISSN 1468-0297. DOI 10.2307/2234131.

[12] NEV'nD'nL, L., (2012). Selected issues of rural inhabitants' perceptions in region among Brno ï BŚeclav Znojmo. In 15th International Colloquium on Regional Sciences. Conference Proceedings. Brno: Masarykova univerzita. pp. 522-528. ISBN 978-80-210-5875-0.

[13] PINCUS., F. L., (1996). Discrimination comes in many forms: Individual, institutional, and structural. The American Behavioral Scientist, vol. 40, iss. 2, pp. 186-194. ISSN 1552-3381. DOI 10.1177/0002764296040002009.

[14] TOMEI, M. Work prejudice 'takes new forms'. [online]. [cit. 2012-05-01]. Dostupný z: $<$ http://news.bbc.co.uk/2/hi/business/6642383.stm>

This paper is supported by GAJU 79/2013/S. 